\title{
The Effect of Leadership and Motivation on Employee Performance at PT Bumi Rajawali in Tangerang
}

\author{
Achmad Rozi \\ Sekolah Tinggi Ilmu Ekonomi Prima Graha Serang-Banten \\ Email: enggus.ahmad@gmail.com
}

(Received: September 6-2019; revised: November 15-2019; published: December 31-2019)

\begin{abstract}
This study aims to determine the effect of leadership and motivation on employee performance at PT. Bumi Rajawali in Tangerang. The method used was explanatory research with a sample of 90 respondents. The analysis technique uses statistical analysis with regression testing, correlation, determination and hypothesis testing. The results of this study leadership has a significant effect on employee performance by $36.2 \%$, hypothesis testing obtained significance $0,000<0.05$. Motivation has a significant effect on employee performance by $45.3 \%$, hypothesis testing obtained significance 0,000 $<0.05$. Leadership and motivation simultaneously have a significant effect on employee performance by $52.1 \%$, hypothesis testing obtained significance of $0,000<0.05$.
\end{abstract}

Keywords: Leadership; Motivation; Employee Performance

\section{INTRODUCTION}

In an organization the existence of human resources (HR) is the most important factor (Blaga \& Jozsef, 2014; Kazakovs, Verdina, \& Arhipova, 2015; Sinambela, 2016; Singodimendjo, 2011; Sulistiyani \& Rosidah, 2013). In organizations or companies that have the same technology, work procedures and organizational structure, but the dynamics or mobility of organizations or companies are different from one another.

In starting a business a leader must be prepared to face the risks that will occur in the future. The leader has a very big role and responsibility in running his business, not only as a motivator and holder of his authority. However, a leader must be able to determine and make the right decisions when faced with confusing choices. So that the decision can be implemented well and beneficial for all parties involved in an organization. One of the hard challenges that must be faced by various leaders now is a continuous flow of problems (Akib \& Dervish, 2015; Niswaty, Juniati, Dervish, Salam, \& Arhas, 2019). According to Ganyang (2018), Leadership is one's ability to direct and influence the behavior of others through effective communication processes to achieve individual, group and company goals. And according to Sedarmayanti (2015: 20) leadership is a process of influencing group activities in the formulation and achievement of goals.

Motivation is a conscious effort to influence one's behavior so as to lead to the achievement of organizational goals (Astuti, Dervish, Saleh, \& Baharuddin, 2019; Diefendorff \& Seaton, 2015; Graham, 2020; Tahir, 2016). According to (Rivai \& Mulyadi, 2012), performance is a general term used by some or all actions or activities of an organization in a period with a reference to a number of standards such as past costs that are projected on the basis of efficiency, responsibility or accountability of management and sort of. Meanwhile, 
166 |Jurnal Ilmiah Ilmu Administrasi Publik: Jurnal Pemikiran dan Penelitian Administrasi Publik Volume 9 Number 2, July- December 2019. Page 165-172

according to (Hasibuan, 2018), "Performance is the result of work achieved by someone in carrying out the tasks assigned to them based on skill, experience, seriousness of time".

To get the expected human resources, every employee is expected to have high work motivation. Given the importance of motivation for each employee, the company needs to continue to keep employee motivation from decreasing (Demircioglu \& Chen, 2019; KanatMaymon, Elimelech, \& Roth, 2020; Taguchi, 2015). One thing that every employee needs to understand is working because he wants to meet his needs, both the needs that are realized and the needs that are not realized. Meeting these needs will certainly motivate employees to work and will increase their impact on good performance and help the company achieve its goals.

\section{METHOD}

The type of research used is associative. The population in this study amounted to 90 respondents PT. Bumi Rajawali in Tangerang. The sampling technique in this study is saturated sampling, where all members of the population are sampled. Thus the sample in this study amounted to 90 respondents. In analyzing the data used the instrument test, classical assumption test, regression, coefficient of determination and hypothesis testing.

\section{RESULT AND DISCUSSION}

The leader has a very big role and responsibility in running his business, not only as a motivator and holder of his authority. However, the leader must decide and make the right decision when faced with the chosen choices.

\section{Descriptive Analysis}

The leader has a very big role and responsibility in running his business, not only as a motivator and holder of his authority. However, a leader must be able to determine and make the right decisions when faced with confusing choices. The results can be seen in table 1 .

Table 1

Descriptive Statistics Analysis Results

Descriptive Statistics

\begin{tabular}{lccc|c|c}
\hline & $\mathrm{N}$ & Minimum & Maximum & \multicolumn{1}{c}{ The mean } & \multicolumn{2}{c}{ Std. Deviation } \\
\hline Leadership (X1) & 90 & 32 & 48 & 38.36 & 4,152 \\
\hline Motivation (X2) & 90 & 30 & 46 & 38.51 & 3,828 \\
\hline Employee Performance (Y) 90 & 32 & 47 & 39.30 & 3,764 \\
\hline Valid N (listwise) & 90 & & & & \\
\hline
\end{tabular}


Leadership obtained a minimum variance of 32 and a maximum variance of 48 with a ratting score of 38.36 with a standard deviation of 4.152 . Motivation obtained a minimum variance of 30 and a maximum variance of 46 with a ratting score of 38.51 with a standard deviation of 3.828. Employee performance obtained a minimum variance of 32 and a maximum variance of 47 with a ratting score of 39.30 with a standard deviation of 3,764 .

\section{Analysis Regression Linear Regression}

This regression test is intended to determine changes in the dependent variable if the independent variable changes. The test results are as follows:

Table 2

Multiple Regression Testing Results

\begin{tabular}{lllll|r|r}
\hline \multicolumn{7}{c}{ Coefficients $^{\text {a }}$} \\
\multicolumn{2}{c}{ Model } & \multicolumn{2}{l}{$\begin{array}{l}\text { Unstandardized } \\
\text { Coefficients }\end{array}$} & $\begin{array}{l}\text { Standardized } \\
\text { Coefficients } \\
\text { Beta }\end{array}$ & & \\
\hline 1 & B & Std. Error & Beta & Sig. \\
\cline { 2 - 8 } & Leadership (X1) & 9,683 & 3,057 & & 3,167 & .002 \\
\cline { 2 - 8 } & Motivation (X2) & .290 & .082 & .319 & 3,518 & .001 \\
\hline
\end{tabular}

a. Dependent Variable: Employee Performance (Y)

Based on the test results in the above table, the regression equation $\mathrm{Y}=9,683+0,290 \mathrm{X} 1$ $+0,481 \mathrm{X} 2$ is obtained. From the equation explained as follows: A constant of 9,683 is interpreted if leadership and motivation are absent, then there is an employee performance value of 9,683 points. Leadership regression coefficient of 0.290 , this number is positive meaning that every time there is an increase in leadership by 0.290 , employee performance will also increase by 0.290 points. The regression coefficient of motivation is 0.481 , this number is positive meaning that every time there is an increase in motivation by 0.481 , the employee's performance will also increase by 0.481 points .

\section{Correlation Coefficient Analysis}

Correlation coefficient analysis is intended to determine the degree of relationship strength of the independent variables on the dependent variable either partially or simultaneously. The test results are as table 3 .

Table 3

Leadership Correlation Coefficient Test Results on Employee Performance. Correlations $^{\mathbf{b}}$

\begin{tabular}{|c|c|c|c|}
\hline & & Leadership (X1) & Employee Performance (Y) \\
\hline \multirow[t]{2}{*}{ Leadership (X1) } & Pearson Correlation & 1 & $.601^{* *}$ \\
\hline & Sig. (2-tailed) & & .000 \\
\hline \multirow[t]{2}{*}{ Employee Performance (Y) } & Pearson Correlation & $.601^{* *}$ & 1 \\
\hline & Sig. (2-tailed) & .000 & \\
\hline
\end{tabular}


168 Jurnal Ilmiah Ilmu Administrasi Publik: Jurnal Pemikiran dan Penelitian Administrasi Publik Volume 9 Number 2, July- December 2019. Page 165-172

Based on the test results obtained a correlation value of 0.601 means that leadership has a strong relationship with employee performance.

Table 4

Motivation Correlation Coefficient Test Results on Employee Performance.

Correlations $^{\mathbf{b}}$

\begin{tabular}{llc|c}
\hline & & Motivation (X2) & $\begin{array}{c}\text { Employee } \\
\text { Performance (Y) }\end{array}$ \\
\hline Motivation (X2) & Pearson Correlation & 1 & $.673^{* *}$ \\
\cline { 2 - 4 } & Sig. (2-tailed) & & .000 \\
\hline \multirow{2}{*}{ Employee Performance (Y) } & Pearson Correlation & $.673^{* *}$ & 1 \\
\cline { 2 - 4 } & Sig. (2-tailed) & .000 & \\
\hline
\end{tabular}

**. Correlation is significant at the 0.01 level (2-tailed).

b. Listwise $\mathrm{N}=90$

Based on the test results obtained by a correlation value of 0.673 means that motivation has a strong relationship with employee performance.

Table 5

Simultaneous Correlation Results of Leadership and Motivation Coefficients on Employee Performance

Model Summary

\begin{tabular}{cc|c|c|c}
\hline & & & & Std. Error of the \\
Model & $\mathrm{R}$ & R Square & Adjusted R Square Estimate & \\
\hline 1 & $.722^{\mathrm{a}}$ & .521 & .510 & 2.634 \\
\hline
\end{tabular}

a. Predictors: (Constant), Motivation (X2), Leadership (X1)

Based on the test results obtained a correlation value of 0.722 means that leadership and motivation simultaneously have a strong relationship to employee performance).

\section{Analysis of the Coefficient of Determination}

Analysis of the coefficient of determination is intended to determine the percentage of influence of the independent variable on the dependent variable either partially or simultaneously. The test results can be seen in table 6 . 
Table 6

Leadership Coefficient Determination Test Results on Employee Performance.

Model Summary

\begin{tabular}{ll|l|l}
\hline Model & R & R Square & Adjusted R Square Estimate
\end{tabular}

a. Predictors: (Constant), Leadership (X1)

Based on the test results obtained a determination value of 0.362 means that leadership has an influence contribution of $36.2 \%$ on employee performance.

Table 7

Motivation Determination Test Results for Employee Performance.

Model Summary

\begin{tabular}{ll|l|l|l}
\hline Model & $\mathrm{R}$ & R Square & Adjusted R Square Estimate & Std. Error of the \\
\hline 1 & $.673^{\mathrm{a}}$ & .453 & .447 & 2.800 \\
\hline
\end{tabular}

a. Predictors: (Constant), Motivation (X2)

Based on the test results obtained a determination value of 0.453 means that motivation has a contribution of $45.3 \%$ influence on employee performance.

\section{Table 8}

Leadership Coefficient Determination Test Results and Motivation on Employee Performance.

\section{Model Summary}

\begin{tabular}{ll|l|l}
\hline Model & R & R Square & Adjusted R Square Estimate
\end{tabular}

a. Predictors: (Constant), Motivation (X2), leadership (X1)

Based on the test results obtained a determination value of 0.521 means that leadership and motivation simultaneously have an influence contribution of $52.1 \%$ on employee performance, while the remaining $47.9 \%$ is influenced by other factors ...

\section{Hypothesis test}

Hypothesis testing with $\mathrm{t}$ test is used to find out which partial hypotheses are accepted. First Hypothesis: There is a significant influence between leadership on employee performance. 
170 Jurnal Ilmiah Ilmu Administrasi Publik: Jurnal Pemikiran dan Penelitian Administrasi Publik Volume 9 Number 2, July- December 2019. Page 165-172

Table 9

Leadership Hypothesis Test Results on Employee Performance. Coefficients $^{\mathrm{a}}$

\begin{tabular}{|c|c|c|c|c|c|c|}
\hline \multirow{2}{*}{\multicolumn{2}{|c|}{ Model }} & \multicolumn{2}{|c|}{$\begin{array}{l}\text { Unstandardized } \\
\text { Coefficients }\end{array}$} & \multirow{2}{*}{$\begin{array}{l}\text { Standardized } \\
\text { Coefficients } \\
\text { Beta }\end{array}$} & \multirow[b]{2}{*}{$\mathrm{t}$} & \multirow[b]{2}{*}{ Sig. } \\
\hline & & B & Std. Error & & & \\
\hline 1 & (Constant) & 18.395 & 2.979 & & 6.176 & .000 \\
\hline & Leadership (X1) & .545 & .077 & 601 & 7.059 & .000 \\
\hline
\end{tabular}

a. Dependent Variable: Employee Performance (Y)

Based on the test results in the above table, tcount> ttable or (7.059>1.987) is obtained, thus the first hypothesis proposed that there is a significant influence between leadership on employee performance is accepted.

Table 10

Motivation Hypothesis Test Results on Employee Performance.

Coefficients $^{\mathrm{a}}$

\begin{tabular}{ccc|c|c|c|c}
\hline \multirow{2}{*}{ Model } & \multicolumn{2}{c|}{$\begin{array}{c}\text { Unstandardized } \\
\text { Coefficients } \\
\end{array}$} & \multicolumn{1}{c|}{$\begin{array}{c}\text { Standardized } \\
\text { Coefficients } \\
\text { B }\end{array}$} & Std. Error & t & Sig. \\
& & Beta & & \\
\hline \multirow{2}{*}{1} & (Constant) & 13.817 & 3.000 & & 4.606 & .000 \\
\cline { 2 - 7 } & Motivasi (X2) & .662 & .078 & .673 & 8.537 & .000 \\
\hline
\end{tabular}

a. Dependent Variable: Employee Performance (Y)

Based on the test results in the above table, tcount> ttable or (8.537> 1.987) is obtained, thus the second hypothesis proposed that there is a significant influence between motivation on employee performance is accepted.

Hypothesis testing with the F test is used to find out which simultaneous hypotheses are accepted. The third hypothesis There is a significant influence between leadership and motivation on employee performance.

Table 11.

Leadership Hypothesis Test Results and Motivation on Employee Performance.

ANOVA ${ }^{\mathrm{a}}$

\begin{tabular}{lll|l|c|c|c}
\hline \multicolumn{1}{c}{ Model } & \multicolumn{1}{c}{ Sum of Squares } & df & Mean Square & F & Sig. \\
\hline 1 & Regression & 657.093 & 2 & 328.547 & 47.339 & $.000^{\mathrm{b}}$ \\
\hline Residual & 603.807 & 87 & 6.940 & & \\
\hline Total & 1260.900 & 89 & & & \\
\hline
\end{tabular}

a. Dependent Variable: employee performance (Y)

b. Predictors: (Constant), Motivation (X2), Leadership (X1) 
Based on the test results in the above table, the value of $F_{\text {count }}>F_{\text {table }}$ or $(47.333>2.710)$ is obtained, thus the third hypothesis proposed that there is a significant influence between leadership and motivation on employee performance is accepted.

\section{CONCLUSION}

Leadership has a significant effect on employee performance with an influence contribution of $36.2 \%$. Hypothesis testing obtained $t_{\text {count }}>t_{\text {table }}$ or (7.059>1.987). Motivation has a significant effect on employee performance with an influence contribution of $45.3 \%$. Hypothesis testing obtained $t_{\text {count }}>t_{\text {table }}$ or (8.537> 1.987). Leadership and motivation have a significant effect on employee performance with a contribution of $52.1 \%$ while the remaining $47.9 \%$ is influenced by other factors. Hypothesis testing obtained value of Fcount> Ftable or (47.333> 2.710).

\section{REFERENCES}

Akib, H., \& Darwis, M. (2015). Pengaruh Gaya Kepemimpinan Transformasional Kepala Sekolah Terhadap Kinerja Guru Pada SMK Negeri 1 Bungoro Kabupaten Pangkep. Jurnal Office, 1(1), 80-87.

Astuti, A., Darwis, M., Saleh, S., \& Baharuddin, A. (2019). Study of Employee work motivation at PT Bank Sulselbar Makassar Main Branch. Jurnal Office, 4(2), 37-52.

Blaga, P., \& Jozsef, B. (2014). Human Resources, Quality Circles and Innovation. Procedia Economics and Finance, 15, 1458-1462. https://doi.org/https://doi.org/10.1016/S22125671(14)00611-X

Demircioglu, M. A., \& Chen, C.-A. (2019). Public employees' use of social media: Its impact on need satisfaction and intrinsic work motivation. Government Information Quarterly, 36(1), 51-60. https://doi.org/https://doi.org/10.1016/j.giq.2018.11.008

Diefendorff, J. M., \& Seaton, G. A. (2015). Work Motivation (J. D. B. T.-I. E. of the S. \& B. S. (Second E. Wright, ed.). https://doi.org/https://doi.org/10.1016/B978-0-08-0970868.22036-9

Graham, S. (2020). An attributional theory of motivation. Contemporary Educational Psychology, 101861. https://doi.org/https://doi.org/10.1016/j.cedpsych.2020.101861

Hasibuan. (2018). Manajemen Sumber Daya Manusia. In Manajemen Sumber Daya Manusia.

Kanat-Maymon, Y., Elimelech, M., \& Roth, G. (2020). Work motivations as antecedents and outcomes of leadership: Integrating self-determination theory and the full range leadership theory. $\quad$ European Management Journal. https://doi.org/https://doi.org/10.1016/j.emj.2020.01.003

Kazakovs, M., Verdina, A., \& Arhipova, I. (2015). Automation of Human Resources Development Planning. Procedia Computer Science, 77, 234-239. https://doi.org/https://doi.org/10.1016/j.procs.2015.12.379 
172 |Jurnal Ilmiah Ilmu Administrasi Publik: Jurnal Pemikiran dan Penelitian Administrasi Publik Volume 9 Number 2, July- December 2019. Page 165-172

Niswaty, R., Juniati, F., Darwis, M., Salam, R., \& Arhas, S. H. (2019). The Effectiveness of Leadership Functions Implementation in The Makassar Departement of Manpower. JPBM (Jurnal Pendidikan Bisnis Dan Manajemen), 5(1), 1-10.

Rivai, V., \& Mulyadi, D. (2012). Kepemimpinan dan Perilaku Organisasi. In Kepemimpinan dan Perilaku Organisasi.

Sinambela, L. P. (2016). Manajemen Sumber Daya Manusia, Membangun Tim Kerja yang Solid untuk Meningkatkan Kinerja.

Singodimendjo. (2011). Manajemen Sumber Daya Manusia. Jakarta: Bumi Aksara.

Sulistiyani, A. T., \& Rosidah. (2013). Manajemen Sumber Daya Manusia. Yogyakarta: Gadjah Mada University Press.

Taguchi, Y. (2015). Factors Forming Work Motivation in Japan. Procedia Manufacturing, 3, 717-722. https://doi.org/https://doi.org/10.1016/j.promfg.2015.07.314

Tahir, N. (2016). Motivasi Kerja Pegawai dalam Pelayanan Publik di Sekretariat Pemerintah Daerah Kabupaten Takalar. Jurnal Ad'ministrare: Jurnal Pemikiran Ilmiah Dan Pendidikan Administrasi Perkantoran, 3(2), 1-10. 